\title{
MAKALAH UNDANGAN \\ KARAKTERISTIK KOMUNITAS FITOPLANKTON DAN FAKTOR LINGKUNGAN DANAU-DANAU KECIL DI PULAU JAWA
}

\author{
Sulastri \\ Peneliti pada Pusat Penelitian Limnologi-Lembaga IImu Pengetahuan Indonesia, Cibinong-Bogor \\ Teregistrasi I tanggal: 17 April 2009; Diterima setelah perbaikan tanggal: 27 April 2009; \\ Disetujui terbit tanggal: 6 Mei 2009
}

\begin{abstract}
ABSTRAK
Perluasan lahan pertanian dan pemukiman di daerah aliran sungai dan pemanfaatan danau yang intensif di Jawa menimbulkan masalah kualitas seperti eutrofikasi yang dicirikan oleh melimpahnya jenis fitoplankton tertentu. Penelitian ini bertujuan untuk mengetahui karakteristik komunitas fitoplankton dan faktor-faktor lingkungan yang menentukan distribusinya di danau-danau kecil di Pulau Jawa. Penelitian dilakukan di 12 danau kecil di Jawa pada tahun 2006. Parameter kualitas air diukur secara langsung menggunakan Horiba U-10. Alkalinitas, nutrient, dan klorofil-a dianalisis menggunakan standard method. Fitoplankton dianalisis secara kuantitatif menggunakan metode Lackey Drop Micro Transect termodifikasi. Pengelompokan komposisi fitoplankton dengan faktor lingkungan menggunakan principle component analysis dan keterkaitan distribusi jenis-jenis fitoplankton dengan faktor lingkungan dianalisis menggunakan canonical corespondence analysis. Komposisi fitoplankton pada umumnya didominansi oleh kelompok Chrysophyta. Pada umumnya kelimpahan fitoplankton dan indeks status trofik (trophic state index) masing-masing $>15.000$ ind./L dan $>50$, menunjukkan perairan danau yang subur, sedangkan indeks keragaman dan indeks dominan fitoplankton masing-masing berkisar 0,787-3,174 dan 0,15-0,941. Analisis principle component analysis menunjukkan bahwa alkalinitas, suhu dan $\mathrm{pH}$ mengelompokkan distribusi Chrysophyta and Euglenophyta. Nitrat, Total N, dan rasio TN/TP mengelompokkan distribusi Chlorophyta, Cyanophyta, dan Phyrrophyta. Analisis canonical corespondence analysis menunjukkan beberapa parameter lingkungan menentukan distribusi jenis-jenis fitoplankton di danau kecil di Jawa.
\end{abstract}

KATAKUNCl: fitoplankton, danau kecil, faktor lingkungan, Jawa

\section{ABSTRACT: Characteristics of phytoplankton community and environmental factors of small lakes in Java Island. By: Sulastri}

The extension of agriculture area as well as urban and intensive utilization of lake in Java may rise quality problem such as eutrophication indicated by the high abundance of certain species. This study was aimed to elucidate the phytoplankton community characteristic and influence of environmental factors to their distribution in small lakes of Java. The study was conducted at 12 small lakes of Java in 2006. Water quality parameters were measured in situ using Horiba U-10 water quality checker. Alkalinity, nutrient and chlorophyll-a were analyzed according to Standard Method. Quantitative analysis of phytoplankton was done using modified Lackey Drop Micro transect. Principle component analysis was used to detect the major environmental variable that classify the composition of phytoplankton. Canonical component analysis was used to elucidate the relationship between phytoplankton species and their environmental factors. The results show that in general Chrysophyta was a dominant group of phytoplankton composition of small lakes of Java. In most cases, the phytoplankton abundance was more than 15,000 ind./L and trophic state index was $>50$ indicating a eutrophic waters. The diversity and dominant indexes of phytoplankton ranged 0.787-3.174 and 0.150.941 , respectively. The principle component analysis show that alkalinity, temperature, and $\mathrm{pH}$ determined in classifying the Chrysophyta while nitrate, TN, and TN/TP ratio were determinants in classifiying the Cyanophyta, Chlorophyta, and Phyrophyta group. Canonical component analysis analysis show that some environmental factors determined the distribution of phytoplankton species in small lakes of Java.

\section{KEYWORDS: $\quad$ phytoplankton, small lakes, environmental factors, Jawa}

\section{PENDAHULUAN}

Pada umumnya danau-danau alami di Jawa memiliki ukuran kecil $\left(<10 \mathrm{~km}^{2}\right)$, dibandingkan di
Sumatera, Sulawesi, dan Papua (Uchida, 1997). Namun jumlahnya cukup banyak dan memiliki peran penting untuk mendukung kehidupan masyarakat di

Korespondensi penulis:

Jl. Raya Jakarta Bogor km 46, Cibinong, Bogor 16911, E-mail: lastri@indo.net.id 
sekitarnya seperti sumber air pembangkit tenaga listrik, perikanan, wisata, dan pengendali banjir.

Danau-danau kecil disebut situ di Jawa Barat, telaga di Jawa Tengah, dan ranu di Jawa Timur. Jumlah danau-danau kecil di Jawa belum banyak diketahui, sedangkan di Jawa Barat khususnya di wilayah Jakarta, Bogor, Bekasi, dan Tangerang berjumlah lebih dari 200 dengan luasan 1-160 ha (Anonimus, 1986).

Semakin padat jumlah penduduk di Jawa, semakin penting, keberadaan fungsi danau-danau kecil untuk berbagai kebutuhan. Kondisi ini dapat dilihat di Danau Klakah, Pakis, dan Grati di Jawa Timur, di mana selain dimanfaatkan untuk wisata dan perikanan tangkap, juga untuk budi daya ikan dalam karamba jaring apung. Danau Menjer di Jawa Tengah, selain dimanfaatkan untuk karamba jaring apung, juga untuk pembangkit tenaga listrik. Pemanfaatan untuk karamba jaring apung dapat mempercepat pengkayaan kandungan nutrient, bahkan menyebabkan blooming fitoplankton seperti Microcystis aeruginosa di Danau Maninjau dan Karangkates Jawa Timur (Syandri, 2000; Brahmana et al., 2002).

Danau-danau kecil merupakan danau yang dangkal sehingga masukkan bahan-bahan organik dari daerah aliran sungai akan mempercepat penyuburan perairan (Wetzel, 2001). Perluasan daerah aliran sungai di Pulau Jawa dapat menyebabkan masalah kualitas air seperti penyuburan perairan atau eutrofikasi. Hasil penelitian menunjukkan bahwa adanya hubungan kondisi penggunaan lahan wilayah daerah aliran sungai dengan komposisi fitoplankton dan kualitas air beberapa danau kecil di Jawa Barat (Sulastri et al., 2008). Gergel et al. 1999 dan Knoll et al., 2003 juga mengatakan bahwa penggunaan lahan di daerah tangkapan air mempengaruhi kondisi kimia air, karena itu danau-danau di wilayah urban menunjukkan peningkatan kandungan nitrat dan fosfat yang mendukung penyuburan dan produktivitas perairan. Respon biologi terhadap peningkatan beban nutrien di daerah aliran sungai antara lain menyebabkan perubahan komposisi fitoplankton dan jaring-jaring makanan ikan serta sering menurunkan populasi zooplankton di perairan danau (Sandy \& Soreal, 2002).

Fitoplankton merupakan produsen primer yang memiliki peran penting dalam siklus materi dan aliran energi sehingga keberadaannya sering mengendalikan pertumbuhan dan reproduksi organisme akuatik lainnya. Oleh karena itu, karakteristik komunitas fitoplankton sering digunakan untuk menilai tingkat kualitas dan mengklasifikasi tingkat kesuburan perairan danau. Perairan yang pada umumnya alkalis dan mengalami pengkayaan nutrien secara terusmenerus didominansi oleh kelompok alga biru hijau seperti Microcystis (Hutchinson, 1967). Penelitian ini bertujuan untuk mengetahui karakteristik komunitas fitoplankton dan faktor-faktor lingkungan yang menentukan distribusinya di danau-danau kecil di Jawa.

\section{BAHAN DAN METODE}

Penelitian ini dilakukan pada tahun 2006 di 12 danau kecil di Jawa (Gambar 1), yakni di Danau Remis (Rm), Nilem (Ni), Gunung (Gn), Cisanti (Cs), Warna (Wn), Menjer (Mj), Pengilon (Pg), Dringo (Dr) Grati (Gt), Pakis (Pk), Pane (Pn), dan Regulo (Rg). Kondisi fisik danau yang mencakup penggunaan lahan daerah aliran sungai dan luasan danau dianalisis di Laboratorium GIS Pusat Penelitian LimnologiLembaga Ilmu Pengetahuan Indonesia menggunakan peta rupa bumi skala 1:25.000 yang diperoleh dari Badan Koordinasi Survei dan Pemetaan Tanah Nasional.

Parameter lingkungan suhu, turbiditas, konduktivitas, $\mathrm{pH}$, dan oksigen terlarut (DO) diukur secara insitu menggunakan water quality checker Horiba-U 10. Kecerahan air diukur dengan cakram Secchi. Contoh air untuk pengukuran parameter lainnya seperti total nitrogen (T-N), amonia, nitrat, total fosfor (T-P), klorofil-a, karbon dioksida bebas $\left(\mathrm{CO}_{2}\right)$, dan alkalinitas diambil dengan menggunakan snatch bottle sampler pada lapisan permukaan, kedalaman cakram Secchi, pada dasar perairan danau atau mendekati kedalaman eufotik, yakni 2 kali kedalaman cakram Secchi atau tergantung dari kedalaman danau. Contoh air diambil pada 3 stasiun untuk setiap danau yang diamati. Contoh air yang diperlukan untuk analisis total nitrogen, amonia, nitrat, dan total fosfor diawet dan dianalisis di Laboratorium Hidrodinamika Pusat Penelitian Limnologi-Lembaga IImu Pengetahuan Indonesia dengan metode yang dijelaskan pada Tabel 1. Contoh klorofil-a diambil dengan menyaring air $200 \mathrm{~mL}$ menggunakan kertas saring GF/C. Alkalinitas dan $\mathrm{CO}_{2}$ diukur langsung di lapangan menggunakan metode titrasi, sedangkan klorofil-a, senyawaan nitrogen, dan fosfor dianalisis menggunakan metode kolorimetrik yang merujuk Anonimus (1992). Nitrit dianalisis di laboratorium menggunakan metode sulfanilamide, sedangkan nitrat dan total nitrogen mengggunakan metode Brucine. Selanjutnya, total fosfor dan orthofosfat dianalisis menggunakan metode asam askorbat. 
Tabel 1. Metode dan alat yang digunakan analisis kualitas air di laboratorium Table 1 . Methods for analysis of water quality in the laboratory

\begin{tabular}{clll}
\hline No. & Parameter/Parameters & \multicolumn{1}{c}{ Metode/Methods } & \multicolumn{1}{c}{ Keterangan/Remarks } \\
\hline 1. & Amonia $\left(\mathrm{N}-\mathrm{NH}_{3}\right)$ & Fenat $^{*}$ & Pre digested using peroxodisulphate \\
2. & Nitrit $\left(\mathrm{NO}_{2}\right)$ & Sulfanilamide* $^{*}$ & Pre digested using peroxodisulphate \\
3. & Nitrat $\left(\mathrm{NO}_{3}\right)$ & Brusin* $^{*}$ & \\
4. & Total $\mathrm{N}$ & Brusin* $^{*}$ & \\
5. & Total $\mathrm{P}$ & Asam askorbat* & \\
6. & Ortofosfat $\left(\mathrm{P}-\mathrm{PO}_{4}\right)$ & Asam askorbat* & \\
7. & Klorofil-a & Kolorimetrik* $^{*}$ & \\
8. & Alkalinitas & Titrimetrik* $^{*}$ & \\
& $\mathrm{CO}_{2}$ & Titrimetrik $^{*}$ & \\
\hline
\end{tabular}

Sumber/Sources: * Anonimus (1992)

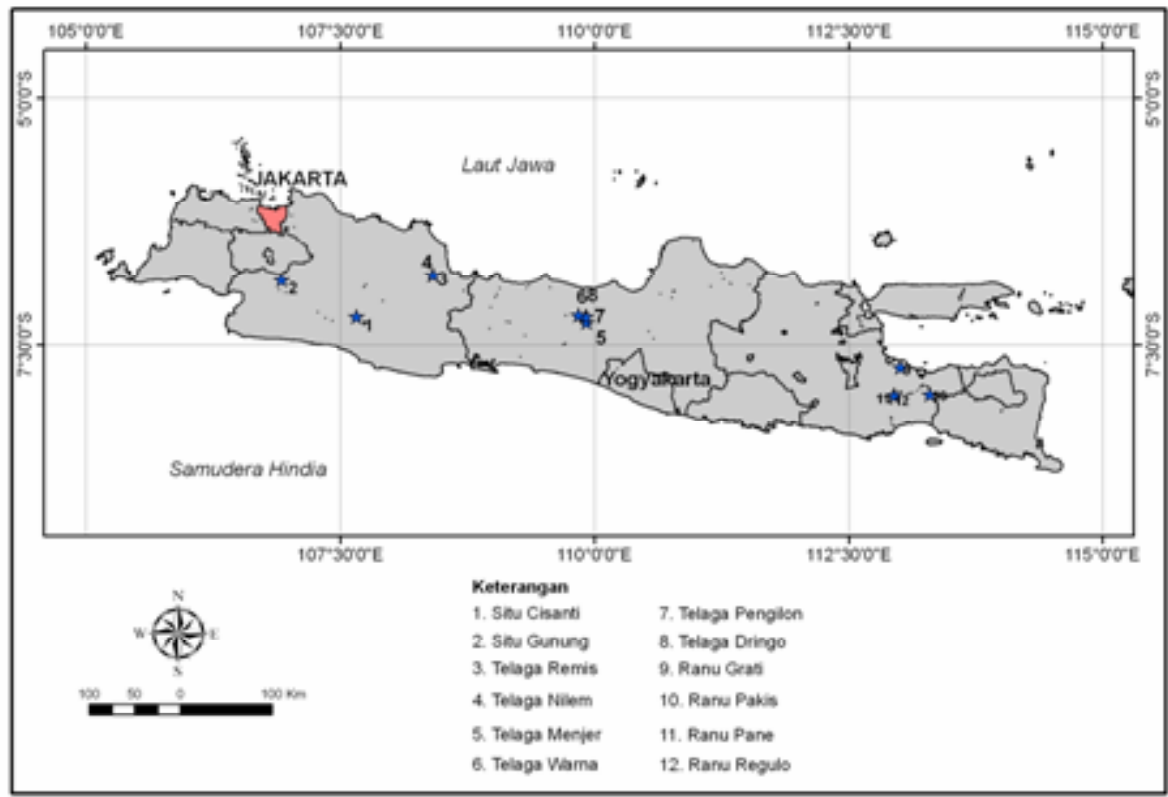

Gambar 1. Lokasi pengambilan data.

Figure 1. Location of data sampling.

Nilai kedalaman cakram Secchi, konsentrasi klorofil-a, dan total fosfor digunakan untuk menghitung indeks kesuburan perairan (trophic state index). Penghitungan indeks tingkat kesuburan perairan merujuk Carlson (1977).

Contoh fitoplankton juga dikoleksi pada titik pengambilan contoh yang sama dengan lokasi pengambilan parameter kualitas air. Contoh fitoplankton diambil dengan menyaring 1 atau $2 \mathrm{~L}$ air melalui plankton net ukuran mata jaring $40 \mu \mathrm{m}$, kemudian diawet dengan larutan Lugol $1 \%$. Jenis-jenis fitoplankton diidentifikasi menggunakan inverted microscope yang merujuk pada Prescott (1951b; 1970); Scott \& Prescott (1961); Baker \& Fabro (1999); Gell et al. (1999). Analisis kuantitatif fitoplankton menggunakan metode Lackey Drop Microtransect termodifikasi (Anonimus, 1992, sedangkan penghitungan indek keragaman dan indeks dominansi fitoplankton merujuk Odum (1971).
Principle component analysis (PCA) digunakan untuk mengetahui faktor lingkungan utama yang menentukan pengelompokkan komposisi fitoplankton dan. Canonical correspondence analysis (CCA) untuk mengetahui keterkaitan jenis-jenis fitoplankton dengan faktor lingkungan (Quinn \& Keough, 2002; Zuur et al 2007). Analisis PCA dan CCA menggunakan program MPSP Versi 3.1.

\section{HASIL DAN BAHASAN}

\section{Deskripsi Kondisi Fisik Danau}

Deskripsi kondisi fisik danau-danau yang diamati disajikan pada Tabel 2. Hasil pemetaan luasan danau menunjukkan Danau Grati merupakan danau terluas. Danau Grati dan Danau Pakis merupakan danau terdalam di Pulau Jawa masing-masing 130 dan 156 m (Chrismadha \& Sulastri, 1996; Thienemann, 1930). Danau Grati dengan kedalaman $130 \mathrm{~m}$ dan ketinggian 
110 m dari permukaan laut (dpl) menunjukkan bahwa dasar danau terletak di bawah permukaan laut. Kedua danau dikelilingi oleh dinding yang terjal dan pembentukannya dari aktivitas vulkanik (Thienemann, 1930). Tipe substrat tepian Danau Grati yang terdiri atas pasir dan berbatu juga mengindikasikan bahwa proses pembentukkannya dari aktivitas vulkanik, serta dasar perairan yang berlumpur diduga hasil proses pengendapan sedimen bertahun-tahun (Chrishmada \& Sulastri, 1996).

Danau-danau kecil di Pulau Jawa pada umumnya selain untuk wisata, dan penangkapan ikan juga dimanfaatkan untuk budi daya ikan seperti di Danau Pakis, Grati, dan Menjer. Danau-danau yang khusus untuk kegiatan wisata pada umumnya dikelola oleh Balai Konservasi Sumber Daya Alam, Departemen Kehutanan seperti Danau Gunung, Warna, Pengilon, Pane, Regulo, dan Remis.

Persentase penggunaan lahan di daerah aliran sungai yang tinggi pada umumnya digunakan untuk sawah, ladang, dan kebun seperti danau-danau di dataran tinggi Dieng (Warna, Pengilon) untuk perkebunan kentang. Kondisi ini dapat dipahami mengingat Pulau Jawa merupakan wilayah padat penduduk sehingga diperlukan daerah pertanian untuk memenuhi kebutuhan pangan. Danau yang persentase penggunaan lahan di sekitarnya didominansi oleh hutan adalah Danau Gunung dan Pakis, Gunung merupakan salah satu danau yang dikelola oleh Balai Konservasi Sumber Daya Alam, Departemen Kehutanan.

Beragamnya kondisi fisik dan lingkungan perairan sekitarnya dapat mencirikan keragaman biota seperti fitoplankton perairan danau tersebut. Seperti dikatakan oleh Abell et al. (2000), karakteristik fisik, kimiawi limnologi dan komunitas biota perairan sangat bervariasi, tergantung pada kondisi geologi, morfometri, iklim, dan juga biogeografi serta pengaruh antropogenik.

\section{Kondisi Lingkungan Perairan}

Hasil pengukuran kondisi lingkungan perairan disajikan pada Tabel 3. Nilai pH berkisar 6,15-7,67, kecuali Danau Warna yang memiliki pH rendah $(2,54)$. Menurut Harris (1980), pH di perairan tawar pada umumnya antara 6-9. Danau-danau kecil di Jawa Barat mempunyai nilai pH 6,41-8,73 (Sulastri et al., 2008). Rendahnya pH di Danau Warna terkait dengan karakteristik Danau Kawah yang aktif yang dicirikan oleh banyaknya mengeluarkan gas-gas seperti $\mathrm{CO}_{2}$ dan $\mathrm{H}_{2} \mathrm{~S}$ dari dalam bumi dan selanjutnya gas-gas tersebut dalam perairan danau membentuk larutan asam sulfat (Tjetjep, 1995; Kusakabe, 1995). Kondisi ini juga didukung oleh tingginya konsentrasi $\mathrm{CO}_{2}$ (Tabel 2) dan sulfat (Sulastri et al., 2008) di Danau Warna.

Suhu perairan menunjukkan kondisi umum di perairan tropis, yakni $18,23-29,07^{\circ} \mathrm{C}$. Suhu yang lebih rendah dijumpai di danau-danau di dataran tinggi seperti Danau Pane, Regulo, dan Dringo (Tabel 2). Oksigen terlarut (DO) berkisar 0,67-10,78 mg/L. Konsentrasi DO yang lebih rendah dijumpai di Danau Warna, Dringo, dan Pakis. Rendahnya DO di Pakis diduga terkait dengan penggunaan oksigen oleh bakteri untuk menguraikan material organik yang berasal dari aktivitas karamba jaring apung.

Nilai alkalinitas pada umumnya tinggi $(23,03-$ 226,06 mg/ $\mathrm{L}_{\text {eq }} \mathrm{CaCO}_{3}$ ), kecuali Danau Warna dan Regulo, masing-masing 0,00 dan 2,28 mg/L $\mathrm{LaCO}_{3}$. Nilai alkalinitas yang tinggi dijumpai di Danau Grati dan Pakis. Menurut Moyle \& Mair (1945; 1966) seperti yang dikutip oleh Boyd (1982), perairan alami yang memiliki konsentrasi alkalinitas $40 \mathrm{mg} / \mathrm{L}$ atau lebih dianggap sebagai perairan produktif atau subur.

Konsentrasi nitrat $\left(\mathrm{N}-\mathrm{NO}_{3}\right)$ di beberapa danau menunjukkan nilai yang tinggi (2,376 dan 1,067 mg/ L) seperti di Danau Menjer dan Pengilon. Konsentrasi T-N yang tinggi juga dijumpai di kedua danau tersebut (2,878 dan1,730 mg/L). Di perairan alami, konsentrasi nitrat yang tinggi pada umumnya mencapai $1 \mathrm{mg} / \mathrm{L}$ (Goldman \& Horne, 1983). Konsentrasi nitrat yang tinggi diduga berasal dari aktivitas pertanian di sekitarnya. Danau Menjer dan Pengilon dikelilingi oleh dinding yang terjal dan penggunaan lahan untuk ladang dan perkebunan (Tabel 2) sehingga sedimen mudah tererosi dan terbawa aliran air ke perairan danau. Goldman \& Horne (1983) mengatakan bahwa nitrat merupakan senyawaan yang mudah pindah melalui tanah atau sedimen, sedangkan fosfat lebih terikat pada partikel-partikel sedimen. Di Danau Pakis penggunaan lahan di sekitarnya didominansi oleh pemukiman (Tabel 2), karena itu konsentrasi T-P dan $\mathrm{N}-\mathrm{NH}_{4}$ yang lebih tinggi dari danau lain diduga masukkan dari aktivitas karamba jaring apung dan aktivitas domestik. Konsentrasi nitrit $\left(\mathrm{N}-\mathrm{NO}_{2}\right)$ di danaudanau yang diamati pada umumnya lebih rendah dari $0,06 \mathrm{mg} / \mathrm{L}$ atau di bawah nilai maksimum standar kualitas air yang ditetapkan di Indonesia untuk kegiatan perikanan (Anonimus, 2001).

Pada umumnya rasio TN:TP adalah $>12$, kecuali di Danau Warna, Pakis, Nilem dan Remis, mengindikasikan bahwa pada umumnya unsur pembatas pertumbuhan fitoplankton adalah fosfor (Jorgensen, 1980). 


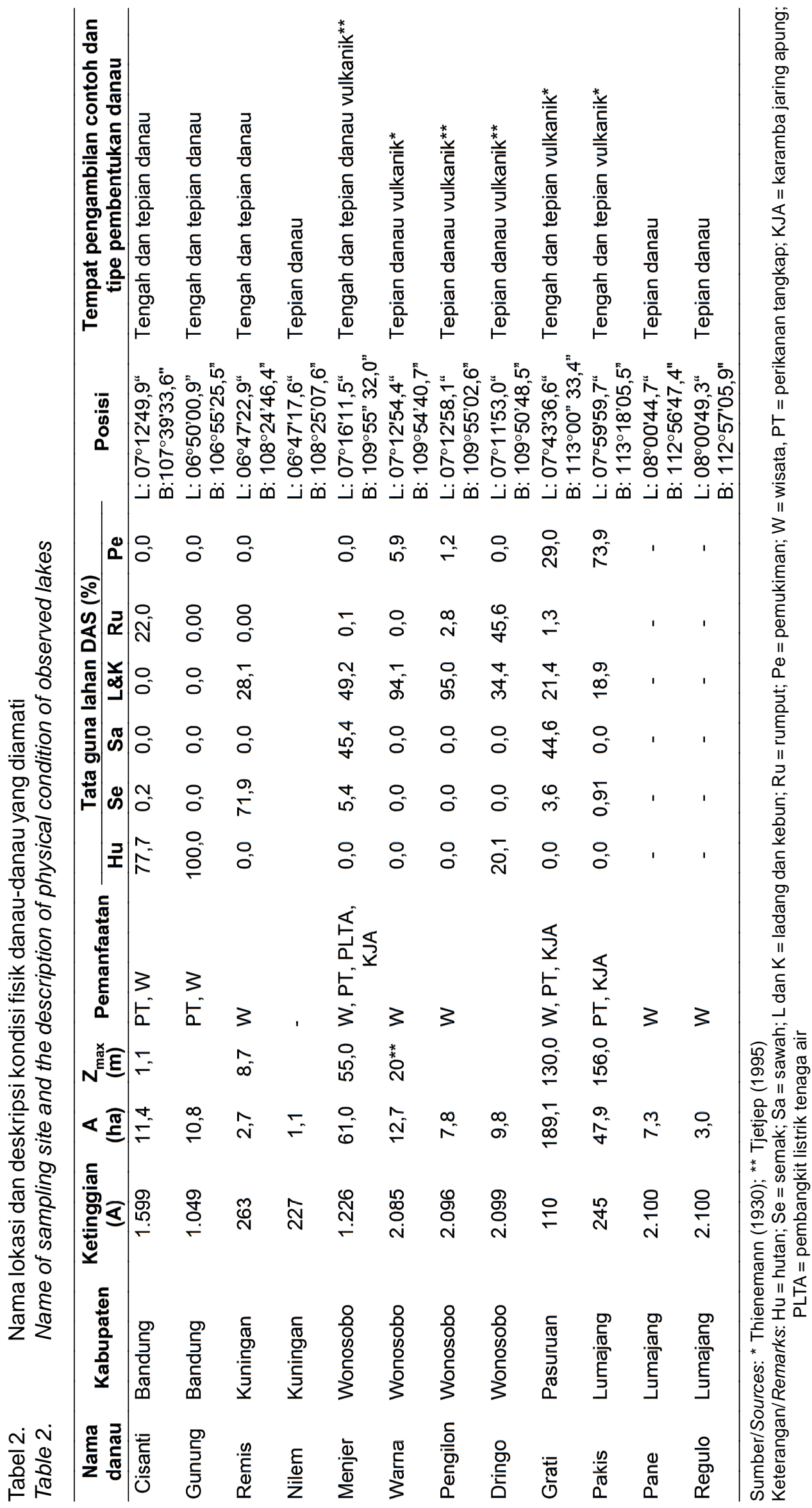




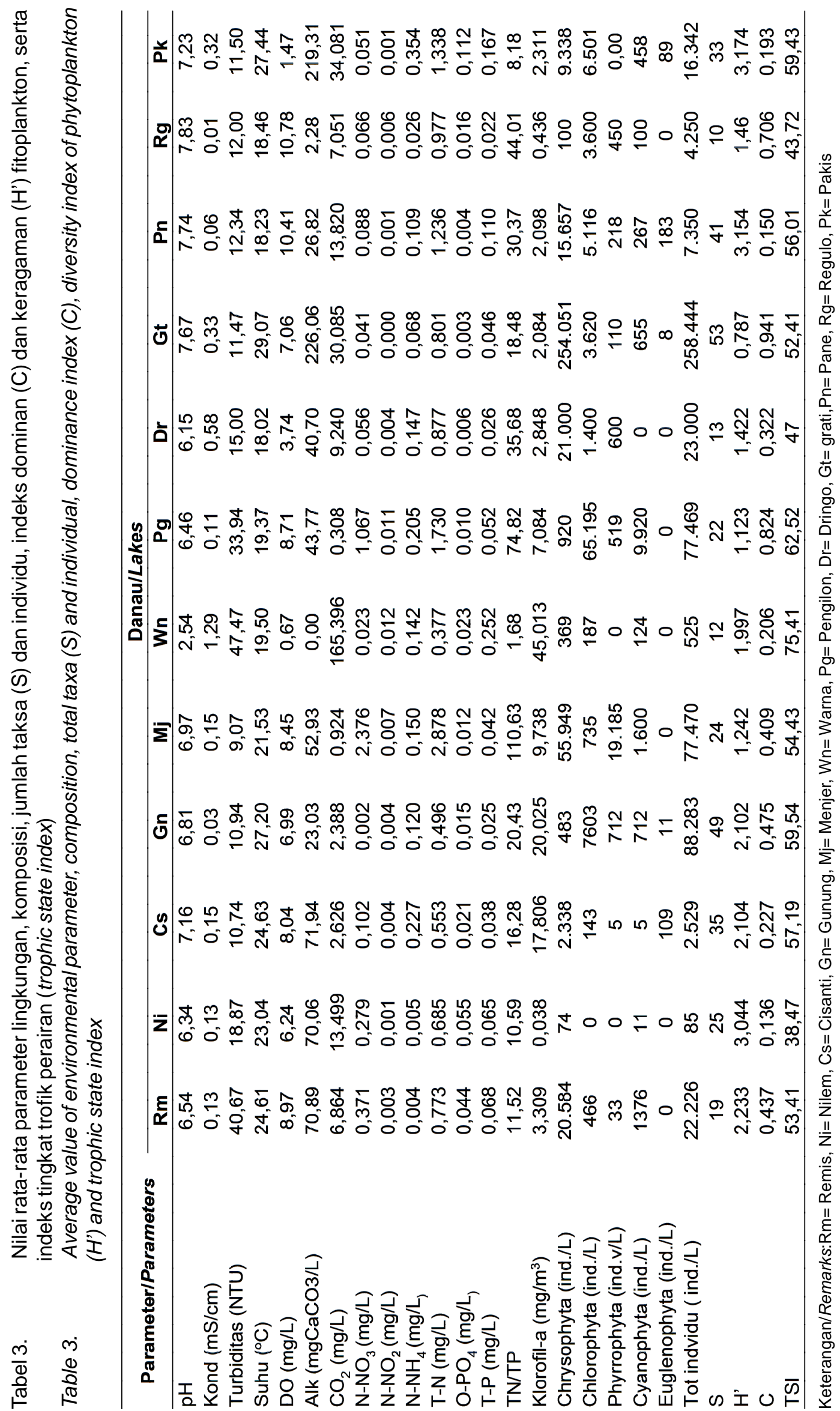




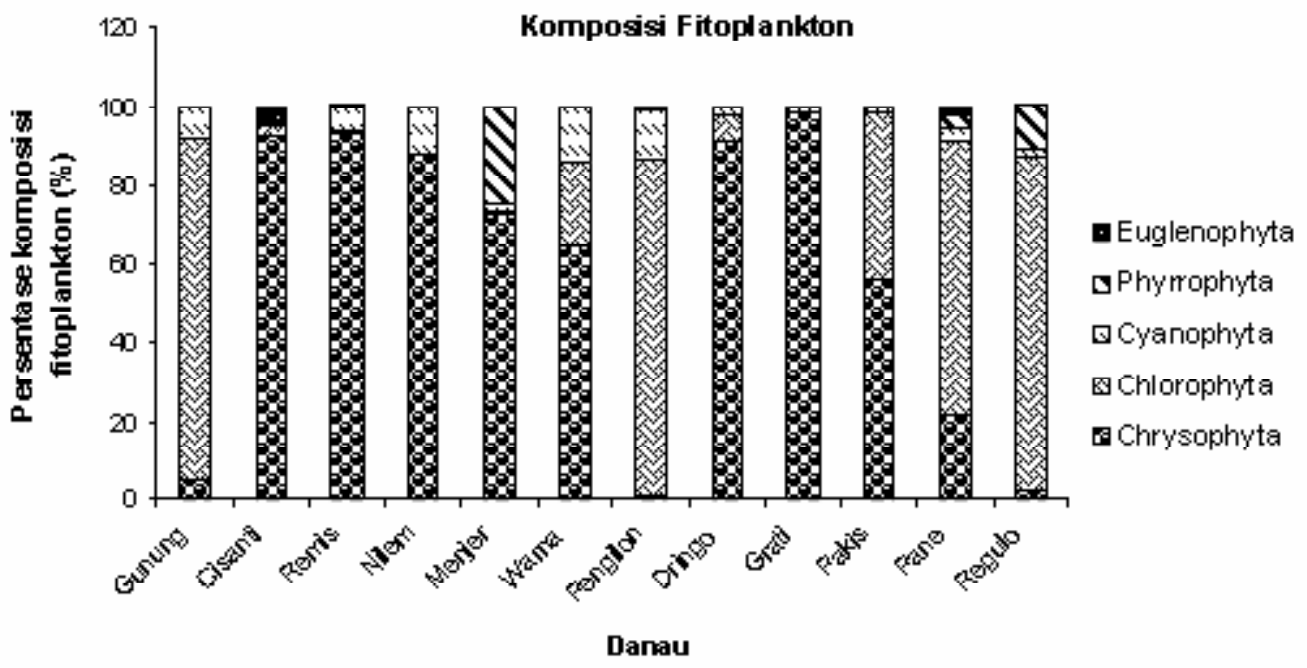

Gambar 2. Persentase komposisi fitoplankton.

Figure 2. The percentage of phytoplankton composition.

Tabel 4. Klasifikasi tingkat kesuburan perairan danau, menurut Carlson (1977)

Table 4. Classification of trophic state for lake, according to Carlson (1977)

\begin{tabular}{cc}
\hline Nilai indek status trofik/Trophic state index value & Status trofil/ \\
\hline $30-40$ & Oligotrofik \\
$40-50$ & Mesotrofik \\
$50-60$ & Medium eutrofik \\
$70-80$ & Eutrofik \\
$>80$ & Hiper eutrofik \\
\hline
\end{tabular}

\section{Komposisi dan Kelimpahan Fitoplankton}

Komposisi fitoplankton di danau-danau kecil di Jawa pada umumnya didominansi oleh kelompok Chrysophyta (Gambar 2) seperti di Cisanti, Remis, Nilem, Menjer, Warna, Dringo, Grati, dan Pakis. Jenisjenis fitoplankton dari kelompok chrysophyta yang mendominansi antara lain Synedra ulna, Sunedrasp., Melosira granulata, dan Diatoma elongata (Tabel 5). Perairan yang subur, kaya nutrient, dan lebih bersifat basah pada umumnya didominansi oleh jenis-jenis dari kelompok diatom (Chrysophyta) (Hutchinson, 1967). Kondisi ini sesuai dengan kondisi lingkungan danau-danau yang diamati yang pada umumnya memilki nilai alkalinitas tinggi (Tabel 2).

Hasil analisis tingkat kesuburan perairan juga menunjukkan bahwa pada umumnya tingkat eutropik danau yang diamati (Tabel 3 ) mempunyai nilai trophic state index sekitar $38,47-75,41$. Klasifikasi tingkat kesuburan perairan dirujuk dari Carlson (1977) seperti disajikan pada Tabel 4.

Di Danau Warna yang tergolong Danau Kawah dan memiliki nilai pH rendah $(2,54)$, komposisi fitoplankton didominansi oleh kelompok diatom (Chrysophyta).
Dominansi kelompok diatom juga umum dijumpai di perairan dengan $\mathrm{pH}$ rendah seperti di Danau Sembuluh, Kalimantan Tengah yang memiliki pH ratarata 4,99; fitoplankton didominansi oleh jenis-jenis dari kelompok diatom seperti Navicula, Tabellaria, dan Rhizosolenia (Sulastri \& Hartoto, 2000). Jenis-jenis fitoplankton dari kelompok Chlorophyta yang dominan di Danau Gunung, Pengilon, Pane, dan Regulo masing-masing adalah Ankistrodesmus falcatus, Scenedesmus bijuga, Ankistrodesmus falcatus, dan Staurastrum perundulatum (Tabel 5).

Jenis-jenis fitoplankton dari kelompok alga biru hijau (Cyanophyta) beracun yang banyak dijumpai di Danau Remis, Gunung, Menjer, dan Grati adalah Microcystis aeruginosa, sedangkan Cylindrospermomsis raciborskii dijumpai di Danau Pengilon, Grati, dan Pakis (Tabel 5). Kondisi ini perlu diwaspadai kemungkinan adanya blooming alga beracun seperti Microcystis aeruginosa, khususnya di Danau Menjer dan Grati yang mendapat pengkayaan nutrien secara terus-menerus dari kegiatan karamba jaring apung. Menurut Hutchinson (1967), perairan yang bersifat basa dan mengalami pengkayaan nutrien secara terus-menerus akan didominansi oleh jenis-jenis alga biru hijau seperti Microcystis. 
Kelimpahan fitoplankton pada umumnya tinggi berkisar 85-258.444 ind./L (Tabel 3). Perairan yang subur (eutrofik) dicirikan oleh kelimpahan fitoplankton lebih dari 15.000 ind./L (Lander, 1979). Kelimpahan fitoplankton yang rendah dijumpai di Danau Nilem, Regulo, dan Warna masing-masing dengan nilai 85, 525, dan 4.250 ind./L. Ditinjau dari T-N, T-P, dan klorofil-a, Danau Nilem dan Regulo dapat digolongkan perairan yang mesotrofik dengan nilai rata-rata parameter tersebut masing-masing untuk Danau Nilem 0,$685 ; 0,065 ;$ dan 0,$038 ; \mathrm{mg} / \mathrm{m}^{3}$ serta untuk Regulo 0,$016 ; 0,977 ;$ dan $0,436 \mathrm{mg} / \mathrm{m}^{3}$. Nilai indeks status trofik kedua danau tersebut juga lebih rendah atau tergolong mesotrofik (38,47 dan 43,72) (Tabel 3). Berdasarkan standar klasifikasi perairan mesotrofik untuk perairan danau, nilai rata-rata konsetrasi T-N, T-P, dan klorofil-a masing-masing adalah 0,$753 ; 0,026$; dan $4,7 \mathrm{mg} / \mathrm{m}^{3}$, sedangkan untuk perairan eutrofik, rata-rata konsentrasi T-N-T-P dan klorofil-a masingmasing adalah 1,$875 ; 0,084 \mathrm{mg} / \mathrm{L}$ dan $14,3 \mathrm{mg} / \mathrm{m}^{3}$ (Wetzel, 2001). Nilai indeks status trofik kedua danau tersebut juga rendah atau tergolong mesotrofik $(38,47$ dan 43,72) (Tabel 3).

Danau Warna memiliki kelimpahan fitoplankton yang rendah, namun konsentrasi klorofil-a dan indeks status trofiknya tinggi $\left(45,013 \mathrm{mg} / \mathrm{m}^{3}\right.$ dan 75,41$)$ (Tabel 3). Fakta ini menunjukkan bahwa konsentrasi klorofila yang tinggi bukan berasal dari fitoplankton dan diduga dari melimpahnya bakteri sulfur berfotosintesis (Photosynthetic sulfur bacteria) yang umum dijumpai di Danau Kawah (Page et al., 2004).

\section{Total Taksa, Indeks Keragaman dan Indeks Dominan Fitoplankton}

Total taksa, indeks keragaman dan indeks dominansi fitoplankton disajikan pada Tabel 3. Total jenis-jenis fitoplankton berkisar 10-52, indeks keragaman fitoplankton berkisar 0,787-3,174 dan indeks dominansi fitoplankton berkisar 0,15-0,941. Total taksa yang rendah dijumpai di Danau Regulo dan Warna, sedangkan total taksa yang tinggi dijumpai di Danau Grati. Danau Warna merupakan danau kawah yang memiliki $\mathrm{pH}$ rendah dan mungkin hanya jenis-jenis tertentu seperti diatom yang umum dijumpai pada perairan $\mathrm{pH}$ rendah seperti danau kawah. Danau Regulo tergolong perairan yang memiliki alkalinitas rendah (Tabel 3). Kondisi ini mungkin yang menyebabkan rendahnya jumlah taksa dan total individu sehingga hanya jenis-jens tertentu yang mampu tumbuh pada perairan ini. Kondisi ini juga ditunjukkan adanya dominansi jenis Staurastrum perundulatum di Danau Regulo (Tabel 5).
Indeks keragaman fitoplankton dapat mencirikan kondisi lingkungan perairan. Jumlah jenis fitoplankton yang tinggi mencirikan sedikitnya gangguan antropogenik pada ekosistem perairan. Danau Grati tergolong perairan yang subur, namun memiliki jumlah taksa yang tinggi (52) dan nilai indeks keragaman fitoplankton yang rendah $(0,787)$. Menurut Rahocevic \& Hollert (2005), hal seperti ini dapat dikaitkan dengan faktor lain seperti perubahan sistem rantai makanan yang menyebabkan perubahan komposisi fitoplankton dan nilai indeks keragaman. Kondisi ini bila dikaitkan dengan komposisi zooplankton di Danau Grati, maka zooplankton didominansi oleh Cladocera dan Rotifer yang pada umumnya memakan partikel dan detritus, sedangkan dari kelompok Copepod hanya 2 jenis yang tergolong herbivora terhadap diatom (Sulastri et al., 2006). Komposisi zooplankton ini dapat menyebabkan banyaknya jenis-jenis fitoplankton dan dominansi jenis tertentu Synedra ulna (Tabel 5). Fakta ini juga ditunjang oleh tingginya dominansi komposisi fitoplankton $(0,941)$. Di samping itu, tingginya dominansi Synedra ulna dapat dikaitkan dengan faktor lingkungan seperti alkalinitas yang tinggi di Danau Grati (Gambar 4 dan 5).

Danau Pane dan Pakis yang diklasifikasikan sebagai perairan yang subur atau eutrofik, memiliki nilai indeks diversitas lebih tinggi $(3,044$ dan 3,174$)$ yang mengisyaratkan adanya keseimbangan komunitas fitoplankton. Kondisi ini terlihat dari nilai indeks dominan fitoplankton yang mendekati nol yang berarti tingkat dominansi komunitas fitoplankton lebih rendah $(0,150$ dan 0,197$)$ dari danau lain (Odum, 1971).

\section{Hubungan Komposisi Fitoplankton dengan Faktor Lingkungan}

Ordinasi komposisi fitoplankton dengan 15 faktor lingkungan menggunakan principle component analysis (PCA) disajikan pada Gambar 3. Hasil ordinasi menunjukkan perairan yang mempunyai alkalinitas dan suhu yang tinggi banyak dijumpai jenisjenis fitoplankton dari kelompok Chrysophyta. Kondisi ini dijumpai di Danau Grati. Selanjutnya, parameter total $\mathrm{N}$, nitrat, dan rasio TN/TP yang tinggi mencirikan perairan di mana banyak dijumpai jenis-jenis Cyanophyta, Chlorohyta, dan Phyrophyta. Kondisi ini dijumpai di Danau Menjer dan Pengilon.

Hasil PCA juga menunjukkan bahwa Danau Warna yang memiliki konsentrasi $\mathrm{CO}_{2}$, konduktivitas dan turbiditas tinggi, serta $\mathrm{pH}$ rendah memiliki total individu dan total taksa fitoplankton yang rendah, namun 
Tabel 5. Komposisi jenis-jenis fitoplankton danau-danau kecil di Jawa Table 5. Species composition of phytoplankton in small lakes of Java

\begin{tabular}{|c|c|c|c|c|c|c|c|c|c|c|c|c|}
\hline Komposisi jenis & 1 & 2 & 3 & 4 & 5 & 6 & 7 & 8 & 9 & 10 & 11 & 12 \\
\hline \multicolumn{13}{|l|}{ Chrysophyta } \\
\hline Amphora ovalis & & $x x$ & & $\mathrm{x}$ & & & & & & & $\mathrm{x}$ & \\
\hline Achantthes linearis & $x$ & & $x$ & $x$ & & $x$ & $x$ & & & & $x$ & \\
\hline Asteronella sp. & & & $x$ & & & & $x$ & & & & & \\
\hline Coconeis sp. & & $\mathrm{x}$ & $x$ & $x$ & & & & & & & & \\
\hline Cymbella ehrenbergii & $x$ & & & & & & & & & & & \\
\hline Cymbella sp. & $x$ & & $x$ & $x$ & $x$ & & & $x x x$ & & $x$ & $x$ & \\
\hline Diatoma elongatum & & & $x x x$ & & $x$ & & $x$ & & $x$ & $x$ & $x$ & \\
\hline D. vulgare & & $x x$ & & & & & $x$ & & & & & \\
\hline Eunotia gracilis & & & & & & $x$ & $x$ & $x$ & $x$ & & $x$ & \\
\hline Eunotia sp. & $x$ & $x$ & $x$ & & & & & & & & & \\
\hline Ephithemia sp. & & $x$ & $x$ & & & & & & & & & \\
\hline Fragilaria construens & $x$ & $x$ & $x$ & $x$ & & $x x$ & $x$ & $x$ & & $x$ & $x$ & \\
\hline F. crotonensis & & $x$ & & & $x$ & & $x$ & $x$ & & $x$ & & \\
\hline G. olivaceum & $x$ & $x$ & & $x$ & $x$ & & $x$ & $x$ & $x$ & & $x$ & \\
\hline Melosira granulata & $x$ & & & & $x x x$ & & & & $x$ & & & \\
\hline Navicula cryptocephala & $x$ & & & $x$ & & $x$ & & & & & $x$ & \\
\hline Navicula spp. & $x$ & $x$ & & $x$ & $x$ & & & & $x$ & $x x$ & $x$ & \\
\hline Nitzschia sp. & & $x$ & $x$ & $x$ & & & & & & & & \\
\hline Pinnularia viridis & & $x$ & $x$ & & & $x$ & $x$ & $x$ & & & $x$ & \\
\hline Synedra ulna & $\mathrm{x}$ & $\mathrm{x}$ & $x$ & $\mathrm{x}$ & $x x x$ & $\mathrm{x}$ & $\mathrm{x}$ & & $x x x$ & $x x$ & $\mathrm{x}$ & $\mathrm{x}$ \\
\hline S. ulna var oxyhincus & & $x$ & $x x x$ & & & & & & & $x$ & & \\
\hline Synedra sp. & & $x$ & $x x x$ & $x$ & $x$ & & $x$ & & & $x x$ & $x$ & $x$ \\
\hline Surirella fenera & & $x$ & $x$ & $x x$ & & & & & & & & $x$ \\
\hline \multicolumn{13}{|l|}{ Chlorophyta } \\
\hline Ankistrodesmus falcatus (Corda) & $x x x$ & & & & & & $\mathrm{x}$ & & & & $x x$ & \\
\hline A. spiralis & $x x x$ & & & & & & & & & & & $x$ \\
\hline Collastrum proboscideum & & & & & & & $x$ & & $x$ & & & \\
\hline C. cambricum & $x$ & & & & & & & & & & & \\
\hline C. sphaericum & $x$ & & & & & & & & & & & \\
\hline Cosmarium identatum & & & & & $x$ & & & & $x$ & $x$ & & \\
\hline C. contractum & & & & & & & & & & $x$ & $x$ & \\
\hline Closterium sp. & $\mathrm{x}$ & & & & & & & & & & $x$ & \\
\hline Crucigenia apiculata & & & & & & & & & $x$ & & & \\
\hline C. quadrata & & & & & & & & & & $x$ & & \\
\hline Crucigenia sp. & & & & & & & & & $x$ & $x$ & & \\
\hline Characium sp. & & & & & & & & & $x$ & & $x$ & \\
\hline Kirchneriella lunaris & $x$ & & & & & & & & $x$ & & & \\
\hline K. obesa var aperta & & & & & & & & & $x$ & & & \\
\hline Oocystis lacustris & & & & & $x$ & & & & $x$ & $x$ & & \\
\hline O. parva & $x$ & & & & & & & & $x$ & $x$ & & \\
\hline \multicolumn{13}{|l|}{ Chlorophyta } \\
\hline P.simplex & & & & & $x$ & & & & & $x$ & & \\
\hline Scenedesmus acuminatus & & & & & & & $x$ & & & & $x$ & \\
\hline S. bijuga & $x$ & $x$ & $x$ & & $x$ & $x$ & $x x x$ & & $x$ & $x$ & $x$ & \\
\hline S. acuatus var platidisca & & & & & $x$ & & & & $x$ & & $x$ & \\
\hline S. quadricauda & $x$ & & & & & & & & $x$ & & $x$ & \\
\hline S. quadricauda var watii & $x$ & & & & & & & & & & & \\
\hline S. longus & & & & & & & & & & & $x$ & \\
\hline S. incrassatus & & & & & & & & & & & $x$ & \\
\hline Staurastrum guwintskii & & & & & $x$ & & $x$ & & $x$ & $x$ & & \\
\hline S. perundulatum & $x$ & & & & & & & & $x$ & $x$ & $x$ & $x x$ \\
\hline S. acanthocephalum & & & & & & & & & $x$ & & & \\
\hline S. spiniceps & $x$ & & & & & & & & $x$ & & & \\
\hline Staurastrum sp. & & & & & & & & $\mathrm{x}$ & $x$ & & & \\
\hline Tetraedron minimum & & & & & & & $\mathrm{x}$ & & $x$ & $\mathrm{x}$ & $\mathrm{x}$ & \\
\hline
\end{tabular}


Lanjutan Tabel 5. Komposisi jenis-jenis fitoplankton

Continued Table 5. Species composition of phytoplankton

\begin{tabular}{|c|c|c|c|c|c|c|c|c|c|c|c|c|}
\hline Komposisi jenis & 1 & 2 & 3 & 4 & 5 & 6 & 7 & 8 & 9 & 10 & 11 & 12 \\
\hline \multicolumn{13}{|l|}{ Cyanophyta } \\
\hline Anabaena circinalis & & & & & & & & & $\mathrm{x}$ & $\mathrm{x}$ & & \\
\hline A. afinis & $x$ & & & & & & & & & $x$ & $x$ & \\
\hline A. planktonica & $x$ & & & & & & & & & & & \\
\hline Anabaena sp. & & & & & & $x$ & & $x$ & $x$ & & & \\
\hline \multicolumn{13}{|l|}{ Cylindrospermopsis } \\
\hline raciborskii & & & & & & & $x$ & & $x$ & $\mathrm{x}$ & $x$ & \\
\hline Merismopedia punctatus & $x$ & $x$ & & & & & & & $x$ & & $x$ & \\
\hline Microcytis aeruginosa & $x$ & & & & $x$ & & & & $x$ & & & \\
\hline Oscillatoria tenuis & $x$ & & $\mathrm{x}$ & $x$ & & & & & $x$ & $x$ & $x$ & $x$ \\
\hline Oscillatoria sp. & & & $x$ & $x$ & & $x$ & $x$ & & & & & \\
\hline \multicolumn{13}{|l|}{ Pyrrophyta } \\
\hline Ceratium hirudinella & & & & & $x$ & & & & & & $x$ & \\
\hline Glenodinium quadridens & & & & & & & $x$ & & $x$ & & $x$ & $x$ \\
\hline Peridinium cinctum & $x$ & & $x$ & & $x$ & & $x$ & & $x$ & & & \\
\hline Peridinium pussilum & $x$ & $x$ & & & & & $x$ & & $x$ & & $x$ & $\mathrm{x}$ \\
\hline \multicolumn{13}{|l|}{ Euglenophyta } \\
\hline Trachelomonas hispida & $\mathrm{x}$ & $\mathrm{x}$ & & & & & & & & $\mathrm{x}$ & $\mathrm{x}$ & \\
\hline
\end{tabular}

Keterangan/Remarks:1: Gunung; 2: Cisanti; 3: Remis; 4: Nilem; 5: Menjer; 6: Warna; 7: Pengilon; 8: Dringo; 9: Grati; 10: Pakis; 11: Pane; 12: Regulo, ${ }^{* * *}$ : dominant; ** banyak dijumpai; * dijumpai dalam jumlah sedikit

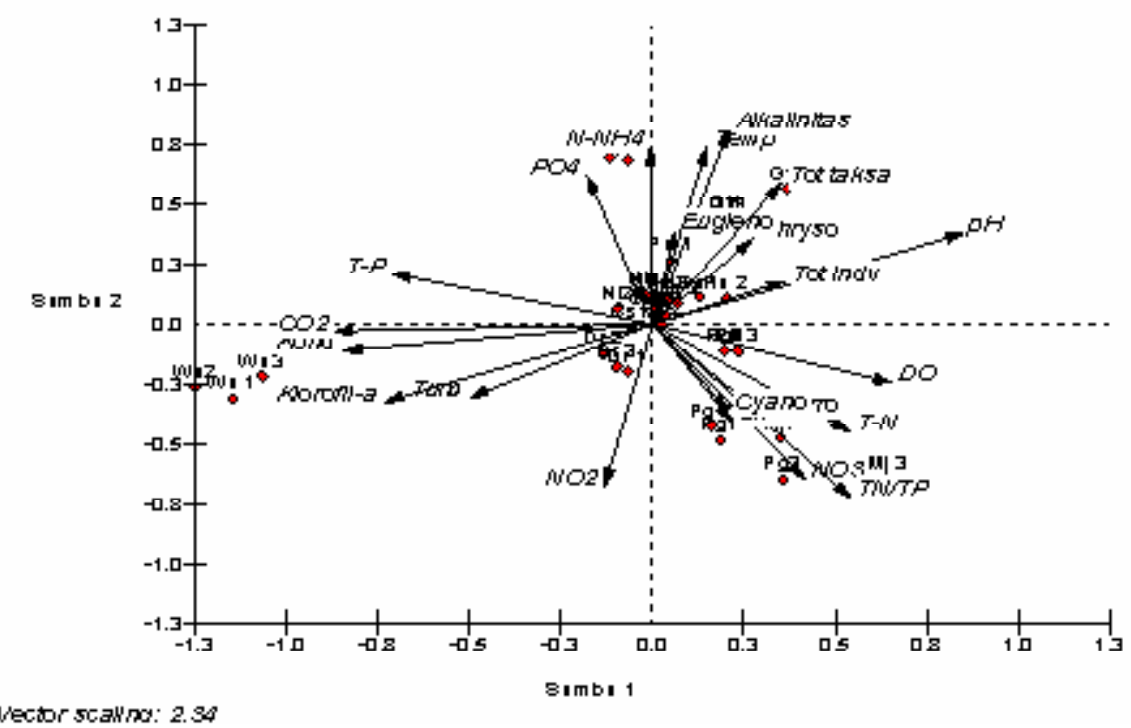

Gambar 3. Hasil analisis komponen utama (principal component analysis) 12 danau dengan 15 faktor lingkungan dan 5 kelompok fitoplankton.

Figure 3. Principal component analysis ordination from 12 sites (lakes) by 15 environmental factors and 5 groups of phytoplankton.

memiliki konsentrasi klorofil-a yang tinggi. Tingginya klorofil-a di Danau Warna diduga berasal dari bakteri sulfur berfotosintesis (photosynthetic sulfur bacteria) yang umum dijumpai di danau kawah (Page et al., 2004).

Hasil PCA menunjukkan bahwa distribusi jenisjenis fitoplankton berkorelasi tinggi dengan faktor lingkungan yang ditunjukan oleh hasil perhitungan species environmental correlation sumbu 1, 2, 3, dan 4 masing-masing adalah $98,96,96$, dan $97 \%$. Nilai $\mathrm{pH}$, suhu, dan konduktivitas menentukan distribusi jenis fitoplankton masing-masing 50,54 , dan $61 \%$, Selanjutnya, alkalinitas, nitrat, nitrit, T-N, dan rasio TN:TP menentukan distribusi jenis-jenis fitoplankton, masing-masing $50,86,66,84$, dan $86 \%$. 


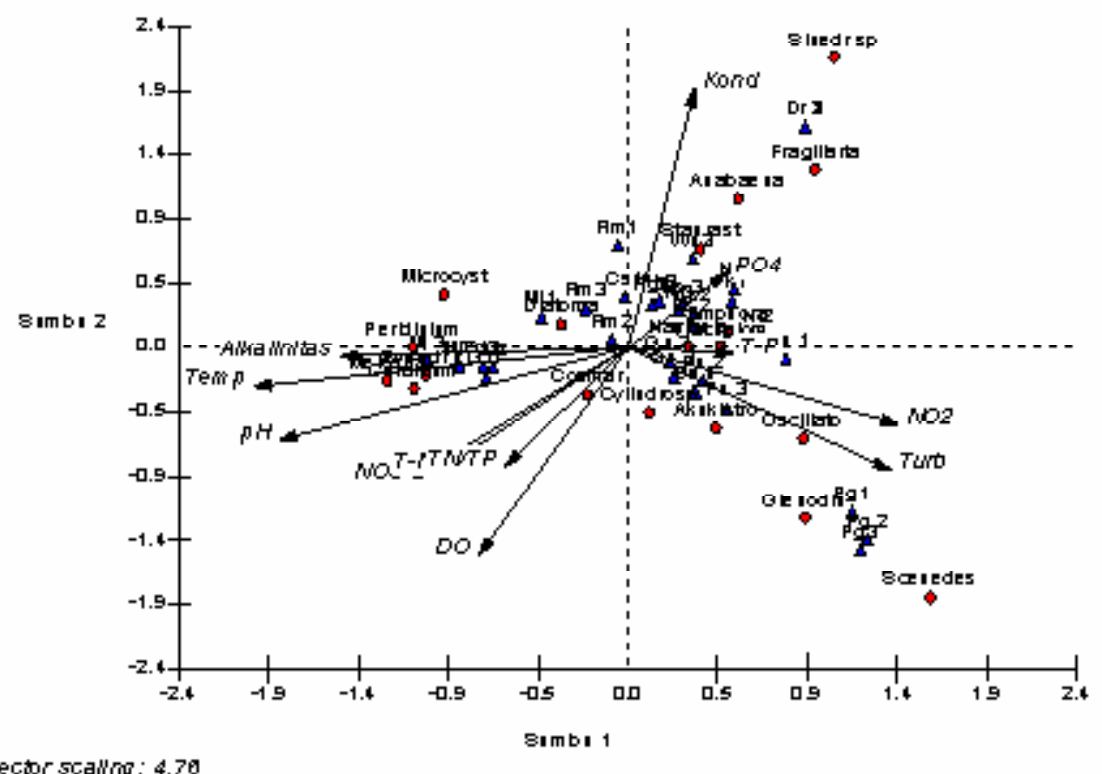

Gambar 4. Hasil canonical corespondence analysis 12 danau dengan 14 faktor lingkungan lingkungan terhadap jenis-jenis fitoplankton dominan dan umum dijumpai antara sumbu 1 dan 2.

Figure 4. Canonical corespondence analysis ordination from 12 sites (lakes) by 14 environmental factors to dominant and common species of phytoplankton found between axes 1 and 2 .

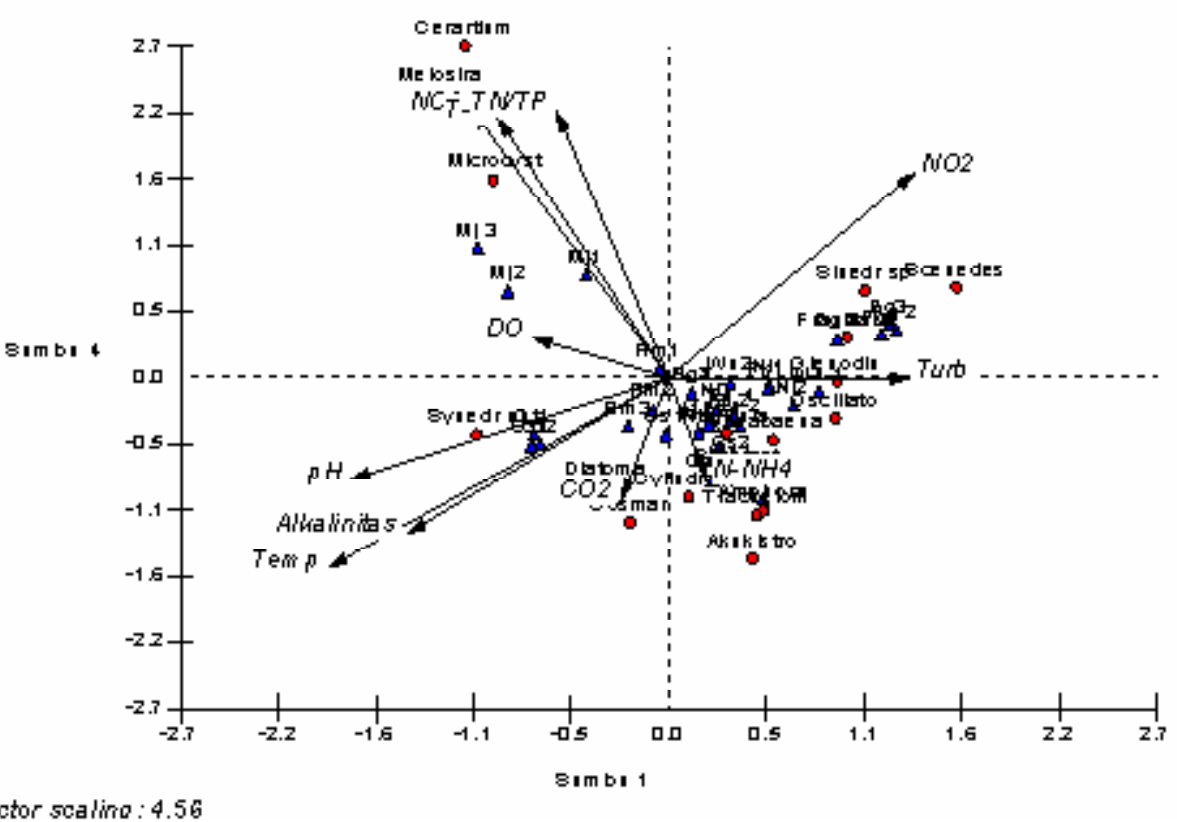

Gambar 5. Hasil canonical correspondence analysis 12 danau dengan 14 faktor lingkungan lingkungan terhadap jenis-jenis fitoplankton dominan dan umum dijumpai antara sumbu 1 dan 4.

Figure 5. Canonical correspondence analysis ordination from 12 sites (lakes) by 14 environmental factors to dominant and common species of phytoplankton found between axes 1 and 4 .

Hasil ordinasi PCA yang disajikan pada Gambar 4 menunjukkan, bahwa alkalinitas dan suhu dan $\mathrm{pH}$ menentukan pengelompokkan distribusi Synedra ulna, Melosira granulata, Ceratium hirudinela, dan
Peridinium sp. Selanjutnya, konduktivitas menentukan pengelompokkan distribusi Fragillaria construen, Synedra sp., Staurastrum sp., serta Anabaena sp. Parameter nitrit dan turbiditas menentukan 
pengelompokkan distribusi Oscillatoria sp., Ankistrodesmus falcatus dan Glenodinium sp.

Hasil ordinasi PCA antara variabel lingkungan dan jenis-jenis fitoplankton pada sumbu 1 dan 4 (Gambar 5) menunjukkan bahwa alkalinitas, $\mathrm{pH}$, dan suhu menentukan pengelompokkan distribusi Synedra ulna, sedangkan nitrat, T-N, dan rasio TN/TP menentukan pengelompokkan distribusi Microcystis aeruginosa, Melosira granulata, dan Ceratium hirudinela. Dari fakta ini distribusi Melosira granulata dan Ceratium hirudinela selain ditentukan oleh faktor suhu, alkalinitas dan $\mathrm{pH}$ (Gambar 4), juga ditentukan oleh faktor lingkungan lain seperti nitrat, T-TN, dan rasio TN/TP. Hasil ordinasi juga menunjukkan bahwa pengelompokkan distribusi jenis-jenis seperti Ankistrodesmus falcatus, Cylindrospermopsis raciborskii, dan Trahelomonas hispida ditentukan oleh faktor lingkungan $\mathrm{N}-\mathrm{NH}_{4}$. Menurut Harris (1986), selain parameter fisik, parameter kimiawi, dan rasio TN:TP juga menentukan peluang melimpahnya jenis-jenis fitoplankton seperti Microcystis aeruginosa dan Melosira. Microcystis aeruginosa memiliki peluang melimpah pada kondisi kolom perairan yang stabil dan rasio TN:TP $>50$. Menurut Reynold (1984), Microcystis juga melimpah pada perairan yang memiliki konsentrasi nutrien yang tinggi.

\section{KESIMPULAN}

Komposisi komunitas fitoplankton danau-danau kecil di Jawa pada umumnya didominansi oleh kelompok Chrysophyta. Synedra ulna, Synedra sp., Melosira granulata, Diatoma elongata, dan Amphora ovalis. Kelimpahan fitoplankton dan indeks status trofik pada umumnya tinggi, menunjukkan kondisi perairan pada tingkat eutrofik. Hasil analisis principal component analysis menunjukkan alkalinitas dengan suhu dan $\mathrm{pH}$ terlihat menentukan distribusi kelompok Chrysophyta. Hasil analisis canonical correspondence analysis juga menunjukkan beberapa faktor lingkungan menentukan distribusi jenis-jenis fitoplankton di perairan.

\section{PERSANTUNAN}

Kegiatan dari hasil riset pengembangan kriteria limnologi danau-danau dangkal di Jawa, T. A. 2006, dibiayai Pusat Penelitian Limnologi-Lembaga IImu Pengetahuan Indonesia. Ucapan terima kasih disampaikan kepada Pusat Penelitian LimnologiLembaga Ilmu Pengetahuan Indonesia atas fasilitas dan dukungan yang diberikan sehingga penelitian ini dapat dilakukan. Ucapan terima kasih juga disampaikan kepada Sdr. Yoyok Sudarso, S.Si., MS. atas saran-saran dalam analisis statistik, Sdr. Sulung Nomosatriyo, S.Si., dan anggota tim peneliti lain yang terlibat dalam kegiatan proyek atas bantuannya dalam penelitian ini.

\section{DAFTAR PUSTAKA}

Anonimus. 1986. Inventarisasi Data Situ-Situ di Wilayah BOTABEK. Badan Pemerintah Daerah Propinsi Daerah Tingkat I Jawa Barat. 94 pp.

Anonimus. 1992. Standard Methods for the Examination of the Water and Waste Water $17^{\text {th }}$ Edition. APA-AWWA-WPCF: $1.100 \mathrm{pp}$.

Anonimus. 2001. Peraturan Pemerintah Republik Indonesia No. 82 tahun 2001, tentang Pengelolaan Kualitas Air dan Pengendalian Pencemaran Air. Sekretariat Menteri Negara Kependudukan dan Lingkungan Hidup. 14 pp.

Abell, R. A., D. M. Olson, E. Dinerstein, P. T. Hurley, J. T. Giggs, W. Eichbaum, S. Walters, W. Wettengel, T. Allunt, C. J. Loucks, \& P. Hedao. 2000. Freshwater Ecoregions of North America. A. Conservation Assessment. Island Press. Washington D.C. $319 \mathrm{pp}$.

Baker, P. D. \& L. D. Fabro. 1999. A Guide to Identification of common Blue Green Algae (Cyanoprokaryotes) in Australia. Cooperative R. C. for Freshwater Ecology. Identification Guide. No.25. 43 pp.

Boyd, C. E. 1982. Water Quality in Ponds for Aquaculture. University of Auburn. Birmingham. Alabama. $482 \mathrm{pp}$.

Brahmana, S. S., U. Suyatna, S. Bahri, \& R. Fanshury, 2002. Pencemaran air dan eutrofikasi Waduk Karangkates, Jurnal Penelitian dan Pengembangan Pengairan. (16) 49: 73-81.

Carlson, R. E. 1977. A trophic state index for lakes. Limnology and Oceanography. 22 (2): 361-369.

Chrismada, T. \& Sulastri. 1996. Kondisi limnologis Ranu Grati, Jawa Timur. Prosiding Ekspose Hasil Penelitian Limnologi-Lembaga IImu Pengetahuan Indonesia. 1996. Lembaga IImu Pengetahuan Indonesia. Pusat Penelitian Dan Pengembangan Limnologi-Lembaga Ilmu Pengetahuan Indonesia. p. 113-120. 
Elliot, S. \& B. Sorrel. 2002. Lake Manager's Handbook, Land-Water Interaction. Ministry for Environment. Wellington. New Zealand. 78 pp.

Gergel, S. E., M. G. Turner, \& T. K. Kratz. 1999. Dissolved organic carbon as an indicator of the scale of watershed influence on lakes and river. Ecological Application, 9: 1.377-1.390.

Gell, S.,R. IImman, \& Sincock. 1999. An illustrated key to common diatom genera from Southern Australia. Identification Guide No.26. University of Adelaide. Australia. 64 pp.

Goldman, C. R. \& A. J. Horne. 1983. Limnology. McGraw-Hill. Book Company. New York: 464 pp.

Hutchinson, G. E. 1967. A. Threatise on Limnology. II. Introduction to Lake Biology and the Limnoplankton. John Weley \& Sons. New York. $1.115 \mathrm{pp}$.

Harris, G. P. 1986. Phytoplankton Ecology, Structure, Function, and Fluctuation. Chapman and Hall. London. New York: 384 pp.

Jorgensen, S. E. 1980. Lake Management. Pergamon Press Ltd. Oxford-Great Britain: 167 pp.

Knoll, L. B., J. Vanini, \& W. N. Renwick. 2003. Phytoplankton primary production and photosynthetic parameters in reservoir along a gradient of watershed land-use. Limnology and Oceanography. 48: 608-617.

Kusakabe, M. 1995. Hazardous crater lakes. Proceeding on the Meeting of Investigation of crater Lakes in Indonesia. UNESCO-ROSTSEA. IHP and Research Center for Limnology. Indonesian Institute of Sciences. p. 1-27.

Lander, L. 1979. Eutrophication of Lake. Causes, Effects and Means for Control, with Emphasis on Lake Rehabilitation. WHO-Regional Office for Europe. ICP/CEP 210. Stockholm. Sweeden. 78 pp.

Moyle, J. B. 1945. Some chemical factors influencing the distribution of aquatic plants in Minnesota. Amer. Midl. Natur. 34: 402-420.
Mairs, D. F. 1966. A total alkalinity atlas for Maine lake waters. Limnology Oceanography. 11: 86-72.

Odum, T. P. 1971. Fundamental Ecology. $3^{\text {rd }}$ edition. W. B. Saunders. Philadelphia. 574 pp.

Page, K. A, S. A. Connon, \& S, J. Giovannoni, 2004. Representative freshwater bacterioplankton isolated from crater lake. App. Environment Microbiology. 70 (11): 6.542-6.550.

Prescott, G. W. 1951. Algae of the western great lakes area. Cranbrook Institute of Science. Bloomfield Hills. Michigan. Bulletin. No.31.

Prescott, G. W. 1970. The Freshwater Algae. W. M. Brown Company Publisher. 347 pp.

Quiin, G. P. \& M. J. Keuough. 2002. Experimental Design and Data Analysis for Biologist. Cambrigde University Press. 537 pp.

Reynold, C. S. 1984. The Ecology of Phytoplankton. Cambridge University Press. New York: 384 pp.

Rakosevic-Nodevic, L. \& H. Hollert. 2005. Phytoplankton community and chlorophyll-a as trophic status indecs of lake Skandar (Montanegro, Balkkan). ESPR-Environ. Sci. and Pollut. Rest. (12): 146-142.

Scott, A. M. \& G. W. Prescott. 1961. Indonesian desmid. Hydrobiologia. XVII. 132 pp.

Syandri, H. 2000. Dampak karamba jaring apung terhadap kualitas perairan Danau Maninjau. Diskusi Panel Padang Press Clup. 22 Nopember 2000. Padang. 13 pp.

Sulastri, E. Harsono, T. Suryono, \& I. Ridwansyah. 2008. Relationship of land use water quality and phytoplankton community of some small lakes in West Java. Oseanologi dan Limnologi di Indonesia. 34 (2): 307-332.

Sulastri \&. D. I. Hartoto. 2000. A Comparative analysis of phytoplankton communities in some inlands water habitats. Central Kalimantan. Indonesia. Rep. Suwa. Hydrobiol. 12: 7-9. 
Thienemann, A. 1930. Trophiche binnengewaser, limnologishen forshungsreise Java, Sumatera and Bali 1928 and 1929. Archfv Fur Hydrobiologie. Sapplement-Band. VIII. 454 pp.

Tjetjep, W. S. 1995. Mitigation program of crater lakes in Indonesia. Proceeding on the Meeting of Investigation of Crater Lakes in Indonesia. UNESCO-ROSTSEA. IHP and Research Center for Limnology. Indonesian Institute of Sciences. p. 91-104.

Uchida, T. 1997. Study on the characteristics of inland water body in Indonesia. Investigation for realistic technology of tropical Area. Research and Development Center for Limnology-Lembaga IImu Pengetahuan Indonesia in the cooperation with Japan International Cooperation Agency. 56 pp.
Wetzell. 2001. Limnology. Lake and River Ecosystem. $3^{\text {th }}$. Academic Press. New York. London. 1.006 pp.

Zuur, A. F., E. N. leno, \& G. M. Smith. 2007. Analyzing Ecological Data. Springer Science+Business Media. LLC. New York. 685 pp. 